\title{
RESPON PERTUMBUHAN TANAMAN SELADA (Lactuca sativa) TERHADAP PEMBERIAN NUTRISI DAN BEBERAPA MACAM MEDIA TANAM SISTEM HIDROPONIK NFT (NUTRIENT FILM TECHNIQUE)
}

\author{
Lactuca sativa Growth Response on Growth of Nutrition and Some Kinds of \\ Growing Media on NFT (Nutrient Film Technique) Hydroponic System
}

\author{
Mohammad Ato Maulana, Insan Wijaya*, Bejo Suroso \\ Program Studi Agroteknologi, Fakultas Pertanian, UM Jember. \\ * e-mail : insan.wijaya@unmuhjember.ac.id; bejosuroso@unmuhjember.ac.id; \\ mohammadato69@gmail.com
}

\begin{abstract}
ABSTRAK
Tanaman selada memerlukan unsur hara makro dan unsur unsur mikro sesuai dengan kebutuhan yang telah tersedia di dalam larutan nutrisi untuk pertumbuhan dan kualitas tanaman. Untuk memenuhi kebutuhan maka hidroponik merupakan alternatif yang dapat digunakan untuk meningkatkan produktivitas tanaman terutama di lahan sempit. Penelitian ini dilaksanakan di Greenhouse Fakultas Pertanian Universitas Muhammadiyah Jember. Rancangan percobaan yang digunakan dalam penelitian ini menggunakan Rancangan Split Plot RAL yang terdiri dari perlakuan Nutrisi sebagai Petak Utama terdiri tiga taraf yaitu AB Mix (N1), NPK Mutiara 16-16-16 (N2) dan Urea TSP KCl, Gandasil D (N3) demikian juga Media tanaman sebagai Anak Petak sebanyak tiga taraf yaitu Rock woll (M0), Arang sekam (M1) dan Batu bata (M2) dan diulang tiga kali. Analisis data dilakukan dengan uji F dan dlanjutkan dengan uji lanjut Duncan 5\%. Hasil peneltian pemberian nutrisi AB Mix berpengaruh terhadap pertumbuhan tanaman selada pada tinggi tanaman $14 \mathrm{hst}$, selanjutnya media tanam rockwool berpengaruh terhadap pertumbuhan tanaman selada pada variabel pengamatan jumlah helai daun. Pengaruh interaksi nutrisi dan media, berpengaruh pada variabel pengamatan jumlah helai daun dan panjang daun.
\end{abstract}

Kata kunci:Hidroponik NFT, Media, Nutrisi, Selada

\begin{abstract}
Lettuce plants need macro nutrients and micro elements in accordance with the needs that have been available in nutrient solutions for plant growth and quality. To meet the needs, hydroponics is an alternative that can be used to increase crop productivity, especially in narrow areas. This research was conducted at the Greenhouse of the Faculty of Agriculture, University of Muhammadiyah Jember. The experimental design used in this study used the RAL Split Plot Design consisting of Nutrition treatments as the Main Plot consisting of three levels, namely AB Mix (N1), NPK Mutiara 16-16-16 (N2) and Urea TSP KCl, Gandasil D (N3) Likewise, the plant media as plots are as many as three levels, namely Rock Woll (MO), Charcoal Chaff (M1) and Brick (M2) and repeated three times. Data analysis was performed with the F test and followed by Duncan's further test of 5\%. The results of the research on the AB Mix nutrition effect on the growth of lettuce plants at 14 hst plant height, then rockwool planting media influenced the growth of lettuce on the observation variable of the number of leaf blades. The effect of nutrient and media interaction influences the observation variables of the number of leaf strands and leaf length.
\end{abstract}

Keywords: NFT Hydroponics,Media, Nutrition, Lettuce 


\section{PENDAHULUAN}

Sayur adalah komoditas hasil pertanian yang memiliki peningkatan produksi yang tinggi, karena dibutuhkan sehari-hari dan permintaannya cenderung terus menerus meningkat. Sayuran adalah makanan yang dikonsumsi setiap saat oleh masyarakat ssehingga sayuran mempunyai nilai komersial yang cukup tinggi. Sayuran juga termasuk komoditas nabati yang sangat diperlukan oleh tubuh (Irwan dkk, 2005). Tanaman selada umumnya dimakan mentah ataupun disajikan sebagai penghias hidangan. Daunnya mengandung vitamin A, B, dan C yang berguna untuk kesehatan tubuh (Sunarjono, 2007). Menurut Harjono (2001), tanaman selada memiliki fungsi sebagai zat pembangun tubuh, dengan kandungan zat gizi dan vitamin yang cukup banyak dan baik untuk kesehatan masyarakat.

Tanaman selada memerlukan unsur hara makro terdiri atas $\mathrm{C}, \mathrm{H}, \mathrm{N}, \mathrm{O}, \mathrm{N}, \mathrm{P}, \mathrm{K}, \mathrm{Ca}$, $\mathrm{Mg}$, dan $\mathrm{S}$ dan unsur unsur mikro yaitu $\mathrm{Mn}, \mathrm{Cu}, \mathrm{Fe}, \mathrm{Mo}, \mathrm{Zn}, \mathrm{B}$ sesuai dengan kebutuhan yang telah tersedia di dalam larutan nutrisi untuk pertumbuhan dan kualitas tanaman (Wijayani dan Indradewa, 2000). Semakin tinggi suhu larutan nutrisi, oksigen yang terlarut di dalamnya semakin rendah (Morgan, 2005). Oksigen sangat diperlukan untuk berlangsungnya respirasi dalam sel-sel akar dan menghasilkan ATP yang berguna dalam proses pengambilan unsur hara oleh akar tanaman (Mengel dan Kirkby, 1978). Suhu larutan nutrisi mempengaruhi panjang batang, berat segar dan berat kering tanaman selada. Semakin rendah suhu dan berlangsung dalam waktu relatif lama mengakibatkan batang tumbuh lebih pendek, berat segar dan berat kering lebih rendah (Ginting, 2007).

Seiring dengan meningkatnya jumlah penduduk, permintaan pasar pada sektor pangan juga akan semakin meningkat (Roidah, 2014). Namun, hal tersebut tidak diikuti dengan ketersediaan lahan pertanian yang cukup. Penurunan luas lahan pertanian terutama pada sawah mencapai 0,25\% pada tahun 2013 (Pusat Data dan Sistem Informasi Pertanian, 2014).

Hidroponik adalah alternatif yang dapat digunakan untuk meningkatkan produktivitas tanaman terutama di lahan sempit (Siswandi dan Sarwono, 2013). Hidroponik dapat diartikan sebagai teknik budidaya tanaman dengan menggunakan media tanam selain tanah dan memanfaatkan air untuk menyalurkan unsur hara yang dibutuhkan ke setiap tanaman. Hidroponik juga memiliki beberapa keuntungan diantaranya adalah budidayanya yang tidak bergantung iklim, hasil panen yang kontinyu, dan perwatan tanaman yang lebih praktis (Lingga, 2007).

Sistem hidroponik merupakan salah satu cara menghasilkan produk tanaman terutama komoditas sayuran yang berkualitas tinggi secara berkelanjutan (Rosliani dan Sumarni, 2005). Sistem hidroponik NFT dapat diandalkan untuk produksi tanaman skala besar. Nutrisi pada sistem ini selalu mengalir sehingga seluruh netpot yang ada di dalam rangkaian mendapat nutrisi yang cukup. Sistem hidroponik NFT harus dirangkai dengan benar sehingga nutrisi dapat tersirkulasi dengan baik. Kelemahan dari sistem hidroponik NFT ini antara lain, ketersediaan dan pemeliharaan perangkat hidroponik yang rumit dan modal awal yang relatif lebih besar (Herwibowo dan Budiana, 2014).

\section{METODE PENELITIAN}

Penelitian ini dilaksanakan di Greenhouse Fakultas Pertanian Universitas Muhammadiyah Jember, dengan ketingggian tempat \pm 89 meter dpl. Rancangan percobaan yang digunakan dalam penelitian ini menggunakan Rancangan Split Plot RAL yang terdiri dari perlakuan Nutrisi sebagai Petak Utama terdiri tiga taraf yaitu AB Mix (N1), NPK 
Mutiara 16-16-16 (N2) dan Urea TSP KCl, Gandasil D (N3) demikian juga Media tanaman sebagai Anak Petak sebanyak tiga taraf yaitu Rock woll (M0), Arang sekam (M1) dan Batu bata (M2) dan diulang tiga kali. Analisis data dilakukan dengan analisis varian (ANOVA) dengan uji F. Apabila terdapat perbedaan yang nyata maka dilakukan uji lanjut Duncan (DMRT).

Media tanam yang digunakan untuk tanaman selada pada sistem hidroponik yakni Rockwool, arang sekam, batu bata. Penyemaian benih selada dilakukan pada lahan yang sangat dekat dengan area hidroponik supaya mudah dipantau. Ketika bibit selada berumur 2 minggu, bibit selada sudah berdaun (4 daun) lengkap dan siap untuk pindah tanam. Kegiatan pemeliharaan yang akan dilakukan meliputi: Penanaman, Penyulaman, Pengendalian Hama dan Penyakit, pemeliharaan pipa/paralon, Pengukuran Konsentrasi dan $\mathrm{pH}$ nutrisi, Pengukuran volume dan temperatur larutan.

Nutrisi yang digunakan ada tiga macam, yaitu:

- $\mathrm{AB}$ Mix, dengan takaran $3 \mathrm{ml}$ nutrisi $\mathrm{AB}$ Mix di campur dengan 1 liter air.

- NPK Mutiara + Growmore, bahan nutrisi dengan takaran 30 liter air adalah NPK Mutiara (30 gram), Growmore (30 gram).

- Urea + TSP + KCL + Gandasil D, bahan nutrisi dengan takaran 30 liter air adalah Urea (30 gram), TSP (15 gram), KCL (15 Gram), Gandasil D (15 gram).

Variabel pengamatan sebagai berikut : Tinggi Tanaman $(\mathrm{cm})$; Jumlah Helai Daun (Helaian); Panjang Daun (cm); Lebar Daun (cm); Panjang Akar (cm); Berat Berangkasan Basah (gram); dan Berat Basah Akar (gram)

\section{HASIL DAN PEMBAHASAN}

\section{Tinggi Tanaman}

Tabel 1. Pengaruh perlakuan nutrisi terhadap tinggi tanaman selada

\begin{tabular}{lccccc}
\hline \multirow{2}{*}{ Perlakuan Nutrisi } & \multicolumn{5}{c}{ Tinggi Tanaman Selada $(\mathrm{cm})$} \\
\cline { 2 - 6 } & $14 \mathrm{hst}$ & $21 \mathrm{hst}$ & $28 \mathrm{hst}$ & $35 \mathrm{hst}$ & $42 \mathrm{hst}$ \\
\hline N1- AB Mix & $6.22 \mathrm{a}$ & $9,19 \mathrm{a}$ & $12,33 \mathrm{a}$ & $16.56 \mathrm{a}$ & $21.67 \mathrm{a}$ \\
N2- NPK Mutiara, Growmore & $6.19 \mathrm{~b}$ & $9,24 \mathrm{a}$ & $12,30 \mathrm{a}$ & $16.41 \mathrm{a}$ & $21.54 \mathrm{a}$ \\
N3- Urea, TSP, KCL, Gandasil D & $5.00 \mathrm{~b}$ & $7,63 \mathrm{a}$ & $10,04 \mathrm{a}$ & $13.78 \mathrm{~b}$ & $17.74 \mathrm{~b}$ \\
\hline
\end{tabular}

Keterangan : Angka-angka yang disertai denggan huruf yang sama pada kolom yang sama menunjukkan berbeda tidak nyata pada uji duncan 5\%

Tabel 1 menunjukkan bahwa hasil analisis ragam pada perlakuan pengaruh nutrisi terhadap tinggi tanaman umur $(14,35$ dan 42$)$ hst menunjukan berbeda nyata. Perlakuan N1 (AB Mix) berbeda nyata dengan perlakuan N2 (NPK Mutiara, Growmore) dan N3 (Urea, KSP, KCL, Gandasil D). Sebagai perlakuan terbaik yaitu N1 (AB Mix). Keterlambatan pemberian nutrisi atau perbandingan unsur yang tidak tepat akan berakibat fatal terhadap pertumbuhan dan perkembangan tanaman bahkan dapat menyebabkan kematian pada tanaman (Aisyah, 2013). Sedangkan perlakuan Nutrisi terhadap tinggi tanaman pada umur 21 dan 28 hst menunjukan berbeda tidak nyata. 
Tabel 2. Pengaruh perlakuan media terhadap tinggi tanaman selada

\begin{tabular}{lccccc}
\hline \multirow{2}{*}{ Perlakuan Media } & \multicolumn{5}{c}{ Tinggi Tanaman $(\mathrm{cm})$} \\
\cline { 2 - 6 } & $14 \mathrm{hst}$ & $21 \mathrm{hst}$ & $28 \mathrm{hst}$ & $35 \mathrm{hst}$ & $42 \mathrm{hst}$ \\
\hline M0 (Rockwool) & $6.15 \mathrm{a}$ & $9.24 \mathrm{a}$ & $12.37 \mathrm{a}$ & $16.51 \mathrm{a}$ & $20.81 \mathrm{a}$ \\
M1 (Arang sekam) & $5.15 \mathrm{~b}$ & $7.40 \mathrm{~b}$ & $10.07 \mathrm{~b}$ & $14.11 \mathrm{~b}$ & $18.81 \mathrm{~b}$ \\
M2 (Batu bata) & $6.11 \mathrm{a}$ & $9.41 \mathrm{a}$ & $12.22 \mathrm{a}$ & $16.11 \mathrm{a}$ & $21.31 \mathrm{a}$ \\
\hline
\end{tabular}

Keterangan : Angka-angka yang disertai denggan huruf yang sama pada kolom yang sama menunjukkan berbeda tidak nyata pada uji duncan $5 \%$

Tabel 2 menunjukkan bahwa hasil analisis ragam tinggi tanaman selada umur 14 hst pada perlakuan media tanam rockwool (M0) berbeda nyata dengan perlakuan media arang sekam (M1) dan tidak berbeda nyata dengan perlakuan media batu bata (M2). Rata-rata tinggi tanaman tertinggi pada media Rockwool (M0) yaitu $6,15 \mathrm{~cm}$. Pada umur 21 hst pada perlakuan media tanam batu bata (M2) tidak berbeda nyata dengan perlakuan media Rockwool (M0) dan berbeda nyata dengan perlakuan arang sekam (M1). Rata-rata tinggi tanaman tertinggi pada media batu bata (M2) yaitu 9,41 cm. Pada umur (28 dan 35) hst pada perlakuan media Rockwool (M0) berbeda nyata dengan perlakuan arang sekam (M1), dan tidak berbeda nyata dengan perlakuan batu bata (M2). Rata-rata tinggi tanaman tertinggi pada media rockwool (M0) yaitu 12,37 cm (28 hst) dan 16,51 cm (35 hst). Pada umur $42 \mathrm{hst}$ perlakuan batu bata (M2) tidak berbeda nyata dengan perlakuan Rockwool (M0), dan berbeda nyata dengan perlakuan arang sekam (M1). Rata-rata tinggi tanaman tertingggi pada perlakuam batu bata yaitu $21,31 \mathrm{~cm}$. Arang sekam menunjukkan kurang baik kelembabannya pada media tanam yang cukup tinggi dapat dimanfaatkan akar tanaman untuk menyerap air nutrisi dan oksigen dari dalam media tanam (Mechram, 2006).

Tabel 3. Pengaruh interaksi pada perlakuan nutrisi dan media terhadap tinggi tanaman selada

\begin{tabular}{cccccc}
\hline Interaksi Nutrisi & \multicolumn{5}{c}{ Tinggi Tanaman $(\mathrm{cm})$} \\
\cline { 2 - 6 }$(\mathrm{N})$ dan Media (M) & $14 \mathrm{hst}$ & $21 \mathrm{hst}$ & $28 \mathrm{hst}$ & $35 \mathrm{hst}$ & $42 \mathrm{hst}$ \\
\hline N1M0 & $6.56 \mathrm{a}$ & $10.00 \mathrm{a}$ & $13.56 \mathrm{a}$ & $17.56 \mathrm{a}$ & $21.67 \mathrm{a}$ \\
N1M1 & $5.44 \mathrm{a}$ & $7.78 \mathrm{a}$ & $10.67 \mathrm{a}$ & $15.00 \mathrm{a}$ & $19.89 \mathrm{a}$ \\
N1M2 & $6.67 \mathrm{a}$ & $9.78 \mathrm{a}$ & $12.18 \mathrm{a}$ & $17.11 \mathrm{a}$ & $23.44 \mathrm{a}$ \\
N2M0 & $7.22 \mathrm{a}$ & $10.72 \mathrm{a}$ & $13.89 \mathrm{a}$ & $18.67 \mathrm{a}$ & $23.67 \mathrm{a}$ \\
N2M1 & $4.89 \mathrm{a}$ & $7.33 \mathrm{a}$ & $10.00 \mathrm{a}$ & $13.78 \mathrm{a}$ & $18.89 \mathrm{a}$ \\
N2M2 & $6.44 \mathrm{a}$ & $9.67 \mathrm{a}$ & $13.00 \mathrm{a}$ & $16.78 \mathrm{a}$ & $22.06 \mathrm{a}$ \\
N3M0 & $4.67 \mathrm{a}$ & $7.00 \mathrm{a}$ & $9.67 \mathrm{a}$ & $13.33 \mathrm{a}$ & $17.11 \mathrm{a}$ \\
N3M1 & $5.11 \mathrm{a}$ & $7.11 \mathrm{a}$ & $9.56 \mathrm{a}$ & $13.56 \mathrm{a}$ & $17.67 \mathrm{a}$ \\
N3M2 & $5.22 \mathrm{a}$ & $8.78 \mathrm{a}$ & $10.89 \mathrm{a}$ & $14.44 \mathrm{a}$ & $18.44 \mathrm{a}$ \\
\hline
\end{tabular}

Keterangan : Angka-angka yang disertai denggan huruf yang sama pada kolom yang sama menunjukkan berbeda tidak nyata pada uji duncan $5 \%$

Tabel 3 menunjukkan bahwa pengaruh tinggi tanaman pada perlakuan interaksi nutrisi dan media menunjukkan tidak berbeda nyata umur tinggi tanaman yang tertinggi pada umur 14 hst yaitu 7,22 cm (N2M0), tinggi tanaman pada umur 21 hst tinggi tanaman yang tertinggi yaitu 10,77 (N2M0), tinggi tanaman pada umur 28 hst yang tertinggi yaitu $13,89 \mathrm{~cm}$ (N2M0), tinggi tanaman pada umur 35 hst yang tertinggi yaitu 18,67 cm (N2M2), dan tinggi tanaman pada umur $42 \mathrm{hst}$ yang tertinggi yaitu 23,67 cm (N2M2). Sutiyoso (2013) 
menjelaskan bahwa konsentrasi yang terlalu rendah akan menampakkan gejala defisiensi sehingga pertumbuhan tanaman tidak sempurna, sedangkan konsentrasi nutrisi yang berlebihan akan menyebabkan keracunan.

\section{Jumlah helai daun}

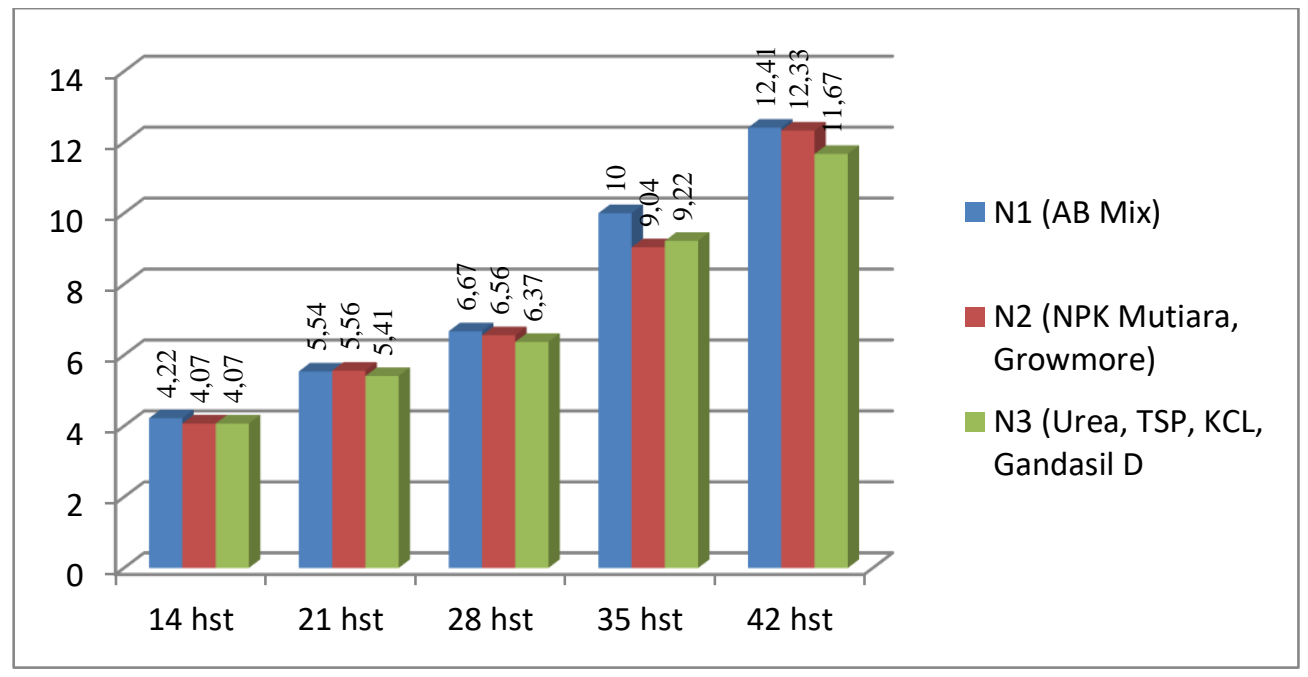

Gambar 1. Pengaruh perlakuan nutrisi terhadap jumlah helai daun

Pada Gambar 1 dapat diketahui bahwa pengaruh perlakuan nutrisi pada jumlah helai daun menunjukkan tidak berbeda nyata, jumlah helai daun umur 14 hst yaitu 4 helai (N1), pada umur 21 hst yaitu 6 helai (N2), pada umur 28 hst yaitu 7 helai (N1), pada umur 35 hst yaitu 10 helai (N1), dan pada umur 42 hst jumlah helai daun terbaik yaitu 12 helai (N1). Menurut Gardner $d k k$, (2007), bahwa penambahan tinggi tanaman secara langsung dapat meningkatkan jumlah daun yang mengandung pigmen klorofil yang berfungsi menyerap cahaya untuk digunakan dalam proses fotosintesis untuk menghasilkan karbohidrat (glukosa) dan oksigen.

Tabel 4. Pengaruh perlakuan media tanam terhadap jumlah helai daun selada

\begin{tabular}{lccccc}
\hline \multirow{2}{*}{ Perlakuan Media } & \multicolumn{5}{c}{ Jumlah helai daun } \\
\cline { 2 - 6 } & $14 \mathrm{hst}$ & $21 \mathrm{hst}$ & $28 \mathrm{hst}$ & $35 \mathrm{hst}$ & $42 \mathrm{hst}$ \\
\hline M0 (Rockwool) & $4.67 \mathrm{a}$ & $5.81 \mathrm{a}$ & $7.04 \mathrm{a}$ & $9.85 \mathrm{a}$ & $12.48 \mathrm{a}$ \\
M1 (Arang sekam) & $3.96 \mathrm{~b}$ & $5.33 \mathrm{~b}$ & $6.33 \mathrm{~b}$ & $9.26 \mathrm{~b}$ & $12.11 \mathrm{~b}$ \\
M2 (Batu bata) & $3.74 \mathrm{~b}$ & $5.25 \mathrm{~b}$ & $6.22 \mathrm{a}$ & $9.15 \mathrm{~b}$ & $11.81 \mathrm{~b}$ \\
\hline
\end{tabular}

Keterangan: Angka-angka yang disertai denggan huruf yang sama dan kolom yang sama menunjukkan berbeda tidak nyata pada uji duncan $5 \%$

Tabel 4 menunjukkan bahwa ragam analisis jumlah helai daun tanaman selada umur $(14,21,35$, dan 42) hst pada perlakuan media rockwool (M0) berbeda nyata dengan rata-rata jumlah helai yaitu 5 helai daun (14 hst), 6 helai daun ( $21 \mathrm{hst}), 10$ helai daun ( $35 \mathrm{hst}), 13$ helai daun (42 hst) dan rata-rata terendah yakni M2 (Batu bata). Sesuai dengan penelitian Bussell, Mckennie (2004), media rockwool merupakan media hidroponik yang paling baik karena memiliki porositas yang baik sehingga media dapat mengatur air dan udara yang diserap oleh tumbuhan.

Tabel 5. Pengaruh interaksi pada perlakuan nutrisi dan media terhadap jumlah helai daun selada 


\begin{tabular}{cccccc}
\hline Interaksi Nutrisi & \multicolumn{5}{c}{ Tinggi Tanaman $(\mathrm{cm})$} \\
\cline { 2 - 6 }$(\mathrm{N})$ dan Media (M) & $14 \mathrm{hst}$ & $21 \mathrm{hst}$ & $28 \mathrm{hst}$ & $35 \mathrm{hst}$ & $42 \mathrm{hst}$ \\
\hline N1M0 & $4.89 \mathrm{a}$ & $6.00 \mathrm{a}$ & $7.22 \mathrm{a}$ & $10.56 \mathrm{a}$ & $12.67 \mathrm{a}$ \\
N1M1 & $4.22 \mathrm{a}$ & $5.22 \mathrm{ef}$ & $6.44 \mathrm{a}$ & $10.11 \mathrm{a}$ & $12.33 \mathrm{a}$ \\
N1M2 & $3.56 \mathrm{a}$ & $5.11 \mathrm{f}$ & $6.33 \mathrm{a}$ & $9.33 \mathrm{a}$ & $12.78 \mathrm{a}$ \\
N2M0 & $4.67 \mathrm{a}$ & $5.56 \mathrm{c}$ & $7.00 \mathrm{a}$ & $9.22 \mathrm{a}$ & $12.78 \mathrm{a}$ \\
N2M1 & $3.67 \mathrm{a}$ & $5.44 \mathrm{~cd}$ & $6.56 \mathrm{a}$ & $8.89 \mathrm{a}$ & $12.44 \mathrm{a}$ \\
N2M2 & $3.89 \mathrm{a}$ & $5.67 \mathrm{~b}$ & $6.11 \mathrm{a}$ & $9.00 \mathrm{a}$ & $11.78 \mathrm{a}$ \\
N3M0 & $4.44 \mathrm{a}$ & $5.89 \mathrm{a}$ & $6.89 \mathrm{a}$ & $9.78 \mathrm{a}$ & $12.00 \mathrm{a}$ \\
N3M1 & $4.00 \mathrm{a}$ & $5.33 \mathrm{de}$ & $6.00 \mathrm{a}$ & $8.78 \mathrm{a}$ & $11.56 \mathrm{a}$ \\
N3M2 & $3.78 \mathrm{a}$ & $5.00 \mathrm{f}$ & $6.22 \mathrm{a}$ & $9.11 \mathrm{a}$ & $11.44 \mathrm{a}$ \\
\hline
\end{tabular}

Keterangan : Angka-angka yang disertai denggan huruf yang sama dan kolom yang sama menunjukkan berbeda tidak nyata pada uji duncan $5 \%$

Tabel 5 menunjukkan hasil analisis ragam jumlah helai daun tanaman selada pada umur 21 hst pada perlakuan interaksi nutrisi dan media menunjukkan berbeda nyata, pada perlakuan nutrisi $\mathrm{AB}$ Mix dan Rockwool (N1M0) rata-rata hasil yang tertinggi dengan 6 helai daun, sementara pada perlakuan (N3M2) menunjukkan rata-rata hasil terendah yakni 5 helai daun.

Dapat diketahui juga bahwa jumlah helai daun berbeda tidak nyata pada umur 14 hst menunjukkan rata-rata jumlah helai tertinggi dengan perlakuan (N1M0) yaitu 5 helai, perlakuan (N1M1) merupakan terendah yaitu 4 helai, jumlah helai daun pada umur $28 \mathrm{hst}$ tertinggi dengan perlakuan (N1M0) yaitu 7 helai, terendah yaitu (N3M1) 6 helai, pada umur 35 hst jumlah helai tertinggi (N1M0) yaitu 11 helai, terendah (N3M1) 9 helai, dan pada umur 42 hst peerlakuan (N2M0) yaitu 13 helai, terendah (N3M2) 12 helai.

\section{Panjang Daun}

Tabel 6. Pengaruh perlakuan nutrisi terhadap panjang daun $(\mathrm{cm})$

\begin{tabular}{lrrrrr}
\hline \multirow{2}{*}{ Perlakuan Nutrisi } & \multicolumn{5}{c}{ Panjang daun $(\mathrm{cm})$} \\
\cline { 2 - 6 } & $14 \mathrm{hst}$ & $21 \mathrm{hst}$ & $28 \mathrm{hst}$ & $35 \mathrm{hst}$ & $42 \mathrm{hst}$ \\
\hline N1- AB Mix & $4.53 \mathrm{a}$ & $6.63 \mathrm{a}$ & $8.39 \mathrm{a}$ & $11.83 \mathrm{a}$ & $13.91 \mathrm{a}$ \\
N2- NPK Mutiara, Growmore & $4.86 \mathrm{a}$ & $6.47 \mathrm{a}$ & $8.33 \mathrm{a}$ & $11.43 \mathrm{a}$ & $13.49 \mathrm{a}$ \\
N3- Urea, TSP, KCL, Gandasil D & $4.06 \mathrm{~b}$ & $6,7 \mathrm{a}$ & $7.23 \mathrm{~b}$ & $9.76 \mathrm{~b}$ & $12.30 \mathrm{~b}$ \\
\hline
\end{tabular}

Keterangan: Angka-angka yang disertai denggan huruf yang sama dan kolom yang sama menunjukkan berbeda tidak nyata pada uji duncan $5 \%$

Tabel 6 menunjukkan hasil analisis ragam rata-rata panjang daun selada berbeda nyata pada umur $(28,35$, dan 42$)$ hst bahwa pemberian nutrisi terbaik yakni (N1) AB Mix, dan pada umur $(28,35$ dan 42$)$ hst perlakuan nutrisi terendah yakni (N3) Urea, TSP, KCL, Gandasil B. Menurut Schwart (2008) konsentrasi hara yang tidak mampu memenuhi kebutuhan tanaman dalam melaksanakan proses fisiologisnya, menyebabkan proses pertumbuhan dan perkembangan yang lambat dan secara visual menunjukkan gejala yang abnormal dalam warna atau struktur.

Dapat di ketahui bahwa pengaruh nutrisi pada perlakuan nutrisi pada panjang daun umur (14 dan 21) hst menunjukkan berbeda tidak nyata, panjang daun yang terpanjang pada umur 14 hst yaitu (N2) 4,86 cm, dan panjang daun yang terpanjang pada umur 21 hst (N1) $6,63 \mathrm{~cm}$, sedangkan pengaruh nutrisi terhadap panjang daun yang terpendek pada umur (14 dan 21) hst adalah (N3). 
Tabel 7. Pengaruh perlakuan media tanam terhadap panjang daun $(\mathrm{cm})$

\begin{tabular}{lccccc}
\hline \multirow{2}{*}{ Perlakuan Media } & \multicolumn{5}{c}{ Panjang daun (cm) } \\
\cline { 2 - 6 } & $14 \mathrm{hst}$ & $21 \mathrm{hst}$ & $28 \mathrm{hst}$ & $35 \mathrm{hst}$ & $42 \mathrm{hst}$ \\
\hline M0 (Rockwool) & $4.52 \mathrm{a}$ & $6.73 \mathrm{a}$ & $8.24 \mathrm{a}$ & $11.64 \mathrm{a}$ & $13.87 \mathrm{a}$ \\
M1 (Arang sekam) & $4.06 \mathrm{a}$ & $5.56 \mathrm{~b}$ & $7.66 \mathrm{a}$ & $10.54 \mathrm{a}$ & $12.68 \mathrm{~b}$ \\
M2 (Batu bata) & $4.87 \mathrm{a}$ & $6.57 \mathrm{a}$ & $8.04 \mathrm{a}$ & $10.89 \mathrm{a}$ & $13.15 \mathrm{ab}$ \\
\hline
\end{tabular}

Keterangan: Angka-angka yang disertai denggan huruf yang sama dan kolom yang sama menunjukkan berbeda tidak nyata pada uji duncan $5 \%$

Pada Tabel 7, hasil analisis ragam panjang daun rata-rata pada perlakuan media pada umur 21 hst yaitu (M0 Rockwool ) 6,73 cm, pada umur 42 hst yakni (M0) Rockwool 13,87 cm. Sedangkan rata-rata terendah pada umur (21 dan 42) hst yakni (M1) Arang sekam. Dapat diketahui bahwa pengaruh media terhadap panjang daun pelakuan media (M0) Rockwool , (M1) arang sekam, (M2) batu bata umur (14, 28, dan 35) hst menunjukkan tidak berbeda nyata, pada umur 14 hst panjang daun terpanjang yakni (M2) 4,87 cm, pada umur 28 hst yakni (M0) 8,24 cm, dan pada umur 35 hst yakni (M0) 11,64 hst.

Tabel 8. Pengaruh Interaksi pada perlakuan nutrisi dan media tanam terhadap panjang daun umur 21 hst

\begin{tabular}{cccccc}
\hline Interaksi Nutrisi & \multicolumn{5}{c}{ Tinggi Tanaman $(\mathrm{cm})$} \\
\cline { 2 - 6 }$(\mathrm{N})$ dan Media (M) & $14 \mathrm{hst}$ & $21 \mathrm{hst}$ & $28 \mathrm{hst}$ & $35 \mathrm{hst}$ & $42 \mathrm{hst}$ \\
\hline N1M0 & $4.26 \mathrm{a}$ & $7.50 \mathrm{a}$ & $8.81 \mathrm{a}$ & $12.71 \mathrm{a}$ & $14.92 \mathrm{a}$ \\
N1M1 & $4.34 \mathrm{a}$ & $5.88 \mathrm{de}$ & $7.91 \mathrm{a}$ & $11.32 \mathrm{a}$ & $13.03 \mathrm{a}$ \\
N1M2 & $5.00 \mathrm{a}$ & $7.06 \mathrm{~b}$ & $8.44 \mathrm{a}$ & $11.61 \mathrm{a}$ & $13.78 \mathrm{a}$ \\
N2M0 & $5.57 \mathrm{a}$ & $7.33 \mathrm{ab}$ & $8.99 \mathrm{a}$ & $12.59 \mathrm{a}$ & $14.28 \mathrm{a}$ \\
N2M1 & $3.82 \mathrm{a}$ & $5.48 \mathrm{f}$ & $7.68 \mathrm{a}$ & $10.43 \mathrm{a}$ & $12.69 \mathrm{a}$ \\
N2M2 & $5.19 \mathrm{a}$ & $6.49 \mathrm{c}$ & $8.31 \mathrm{a}$ & $11.27 \mathrm{a}$ & $13.50 \mathrm{a}$ \\
N3M0 & $3.74 \mathrm{a}$ & $5.36 \mathrm{f}$ & $6.91 \mathrm{a}$ & $9.62 \mathrm{a}$ & $12.43 \mathrm{a}$ \\
N3M1 & $4.01 \mathrm{a}$ & $5.59 \mathrm{ef}$ & $7.40 \mathrm{a}$ & $9.87 \mathrm{a}$ & $12.31 \mathrm{a}$ \\
N3M2 & $4.41 \mathrm{a}$ & $6.17 \mathrm{~cd}$ & $7.38 \mathrm{a}$ & $9.81 \mathrm{a}$ & $12.17 \mathrm{a}$ \\
\hline
\end{tabular}

Keterangan : Angka-angka yang disertai denggan huruf yang sama dan kolom yang sama menunjukkan berbeda tidak nyata pada uji duncan 5\%

Tabel 8 menunjukkan hasil analisis ragam panjang daun rata rata pada perlakuan interaksi (NxM) pada umur 21 hst yakni (N1M0) 7,50, sedangkan pada perlakuan interaksi (N3M0) 5,36 terendah. Dapat diketahui bahwa pengaruh interaksi nutrisi dan media $(\mathrm{NxM})$ terhadap panjang daun tidak berbeda nyata pada umur $(14,28,35$ dan 42) hst, panjang daun pada umur 14 hst yaitu 5, $57 \mathrm{~cm}$ (N2M0), panjang daun umur $28 \mathrm{hst}$ yaitu 8,89 cm (N2M0), panjang daun umur 35 hst yaitu 12,59 cm (N2M0), dan sedangkan pada umur 42 hst yaitu 14, $92 \mathrm{~cm}$ (N1M0).

\section{Lebar Daun}


Hasil analisis sidik ragam menunjukkan bahwa parameter lebar daun pada perlakuan nutrisi berbeda nyata, tetapi perlakuan macam media dan interaksi antara nutrisi dan macam media menunjukkan hasil berbeda tidak nyata.

Tabel 9. Pengaruh perlakuan nutrisi terhadap lebar daun selada

\begin{tabular}{lc}
\hline \multicolumn{1}{c}{ Perlakuan nutrisi } & Lebar daun $(\mathrm{cm})$ \\
\hline N1 (AB Mix) & $10.56 \mathrm{a}$ \\
N2 (NPK Mutiara, Growmore) & $8.48 \mathrm{~b}$ \\
N3 (Urea, TSP, KCL, Gandasil D) & $9.01 \mathrm{~b}$ \\
\hline \multicolumn{1}{c}{ Perlakuan media } & Lebar daun $(\mathrm{cm})$ \\
\hline M0 (Rockwool) & $9.64 \mathrm{a}$ \\
M1 (Arang sekam) & $8.94 \mathrm{a}$ \\
M2 (Batu bata) & $9.47 \mathrm{a}$
\end{tabular}

Keterangan : Angka-angka yang disertai dengan huruf yang sama menunjukkan berbeda tidak nyata pada uji duncan 5\%

Tabel 9, menunjukkan uji analisis pada pengaruh perlakuan nutrisi terhadap lebar daun tanaman selada nutrisi $\mathrm{AB}$ Mix (N1) berbeda nyata dengan perlakuan nutrisi NPK Mutiara, Growmore (N2) dan perlakuan pupuk Urea, TSP, KCL dan Gandasil D (N3). Ratarata jumlah lebar daun pada nutrisi $\mathrm{AB}$ Mix $(\mathrm{N} 1)$ yaitu $11 \mathrm{~cm}$. Jumlah oksigen yang terlarut dalam air juga mempengaruhi pertumbuhan tanaman (Haryanto, 2003).

Tabel 9, dapat diketahui bahwa pengaruh media terhadap lebar daun $(\mathrm{cm})$ menunjukkan berbeda tidak nyata, lebar daun pada (M0) Rockwool menunjukkan hasil yang tertinggi yaitu 9,64 cm, pada media (M2) batu bata hasil yang diperoleh yaitu 9,47 cm, sedangkan (M1) arang sekam menunjukkan hasil yang terendah yaitu $8,94 \mathrm{~cm}$.

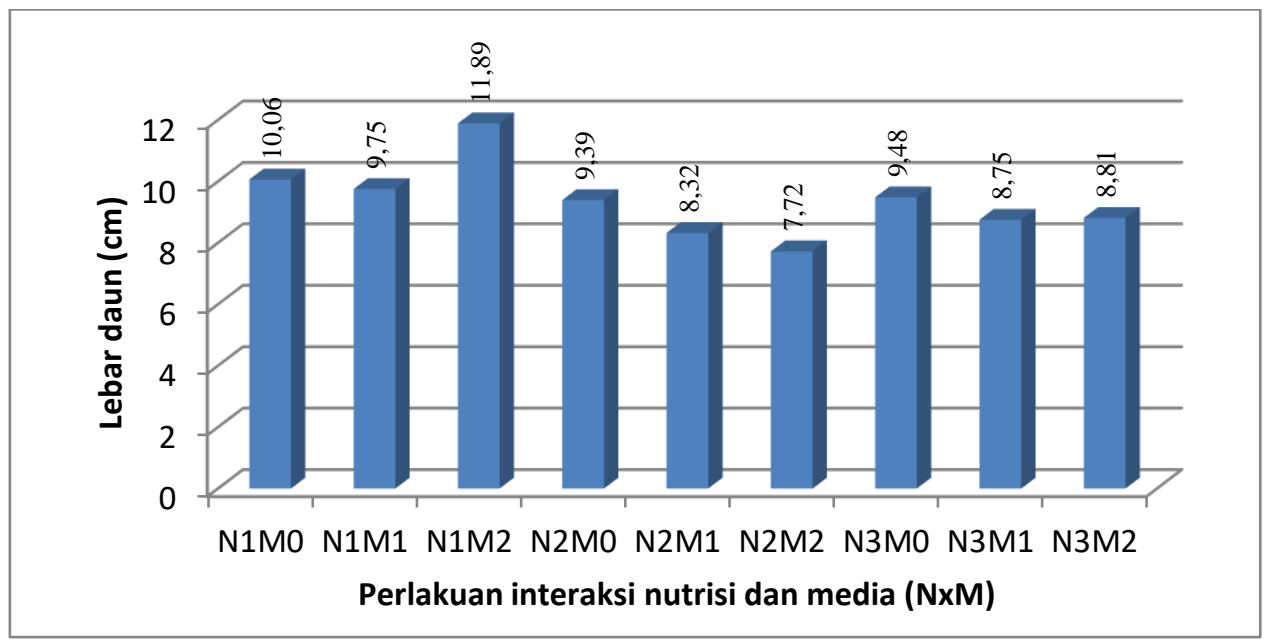

Gambar 2. Pengaruh interaksi nutrisi dan media terhadap lebar daun

Gambar 2, dapat diketahui pada perlakuan (N1M2) menunjukkan hasil yang tertinggi yaitu $11,89 \mathrm{~cm}$, dan pada perlakuan (N2M2) menunjukkan hasil yang rendah yaitu $7,72 \mathrm{~cm}$.

\section{Panjang akar}

Hasil analisis sidik ragam menunjukkan bahwa parameter panjang akar pada perlakuan nutrisi, macam media dan interaksi antara nutrisi dan macam media menunjukkan hasil berbeda tidak nyata 


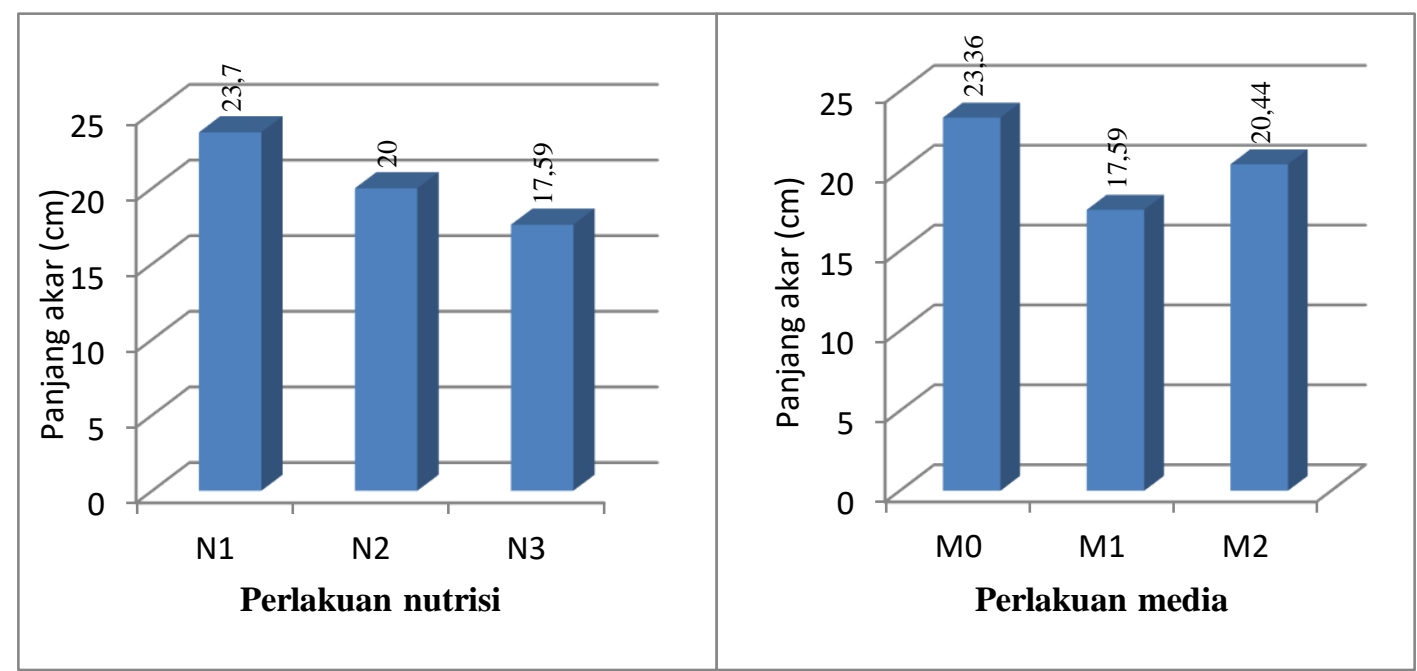

Gambar 3. Pengaruh perlakuan nutrisi dan media terhadap panjang akar $(\mathrm{cm})$

Pada Gambar 3, menunjukkan panjang akar pada perlakuan N1 (AB Mix) hasil yang tertinggi yaitu 23,7 cm, dan pada perlakuan N3(Urea, TSP, KCL, Gandasil D) dan hasil yang terendah yaitu $17,59 \mathrm{~cm}$. Suhu udara lingkungan tentu saja mempengaruhi suhu larutan nutrisi dalam hal ini sebagai media tanaman sehingga menentukan kinerja akar yang selanjutnya menentukan hasil selada (Ginting, $d k k$ 2006).

Gambar 3, perlakuan media M0 (Rockwool) menunjukkan hasil rata-rata panjang akar yang tertinggi 23,36 cm, sedangkan perlakuan M1 (arang sekam) menunjukkan hasil rata-rata terendah yaitu $17,59 \mathrm{~cm}$. Tanaman hidroponik dapat tumbuh baik apabila lingkungan akar memperoleh cukup udara, hara dan air (Nelson, 2009).

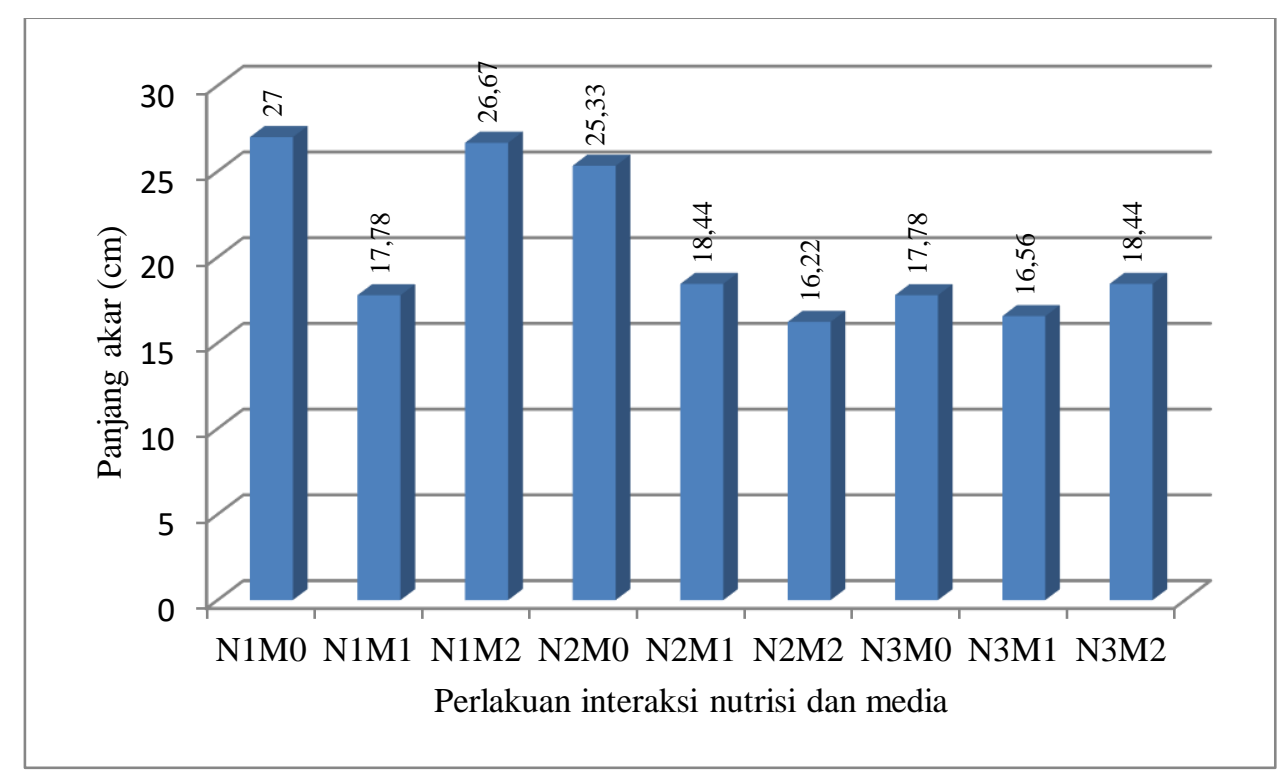

Gambar 4. Pengaruh interaksi nutrisi dan media terhadap panjang akar

Gambar 4, dapat diketahui bahwa panjang akar pada interaksi N1M0 (AB Mix dan Rockwool ) menunjukkan tertinggi yaitu $27 \mathrm{~cm}$, dan pada interaksi N1M1 (AB Mix dan arang sekam) menunjukan panjang akar terendah yaitu $17,78 \mathrm{~cm}$. 


\section{Berat berangkasan basah dan berat akar basah selada}

Tabel 10. Pengaruh media terhadap berangkasan basah dan berat akar basah

\begin{tabular}{lcc}
\hline \multicolumn{1}{c}{$\begin{array}{c}\text { Perlakuan } \\
\text { Media }\end{array}$} & Berat berangkasan basah (gr) & Berat akar basah (gr) \\
\hline M0 (Rockwool) & $47.87 \mathrm{a}$ & $13.07 \mathrm{a}$ \\
M1 (Arang sekam) & $28.93 \mathrm{~b}$ & $5.15 \mathrm{~b}$ \\
M2 (Batu bata) & $53.63 \mathrm{a}$ & $15.06 \mathrm{a}$ \\
\hline
\end{tabular}

Keterangan : Angka-angka yang disertai dengan huruf yang sama pada kolom yang sama menunjukkan berbeda tidak nyata pada uji duncan 5\%

Tabel 10, Hasil analisis ragam rata-rata berat berangkasan basah berbeda nyata. Perlakuan M2 menunjukkan berat brangkasan basah tertinggi yaitu 53, 63 g. Pada perlakuan M2 (batu bata) berbeda nyata dengan perlakuan M1 (arang sekam) akan tetapi tidak berbeda nyata dengan perlakuan M0 (Rockwool).

Tabel 10, dapat diketahui bahwa pengaruh media terhadap berat berangkasan akar basah menunjukkan berbeda nyata, perlakuan M2 (batu bata) sebagai perlakuan terbaik yaitu 15, 06 gram, sedangkan perlakuan M1 (arang sekam) menunjukkan hasil yang terendah yaitu 5,15 gram.

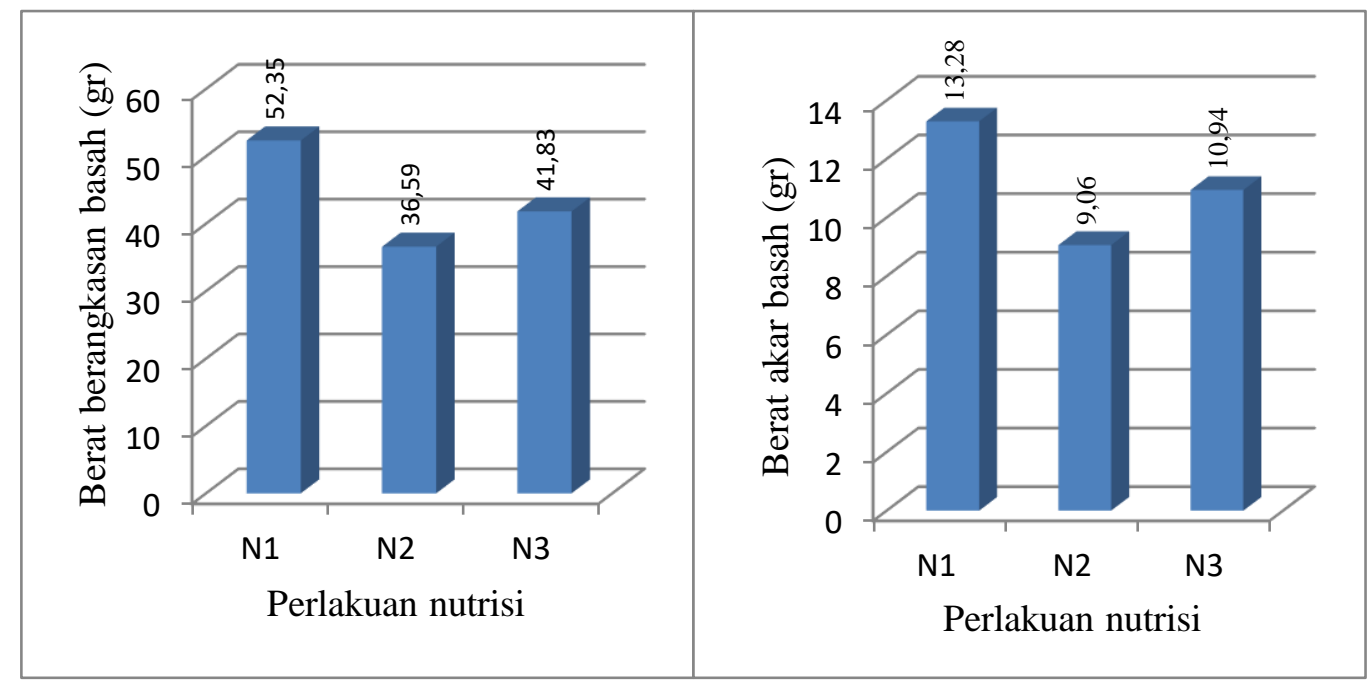

Gambar 5. Pengaruh nutrisi terhadap berat berangkasan basah dan akar basah (gr)

Gambar 5, dapat diketahui pada perlakuan N1 (AB Mix) menunjukkan hasil yang tertinggi yaitu 52, 35 gram, sedangkan N2 (NPK Mutiara, Growmore) menunjukkan hasil yang terendah yaitu 36, 59 gram. Fitter dan Hay (1991), menambahkan rendahnya ketersediaan unsur hara akan memperlambat pertumbuhan tanaman. Masing-masing mempunyai fisiologis tanaman, seperti nitrogen yang mempunyai peranan sangat besar dalam pertumbuhan tanaman.

Gambar 5, dapat diketahui perlakuan N1 (AB Mix) menunjukkan hasil yang tertinggi yaitu 13, 28 gram, sedangkan perlakuan N2 (NPK Mutiara, Growmore) menunjukkan hasil yang terendah yakni 9, 06 gram. Menurut Islami dan Utomo (2009), untuk mendapatkan pertumbuhan yang baik, tanaman harus mempunyai akar dan sistem perakaran yang cukup luas dan dalam untuk memperoleh hara dan air sesuai kebutuhan 
pertumbuhan, namun tanaman tidak selalu memerlukan sitem perakaran yang luas dan dalam pada kondisi hara yang sudah mencukupi.

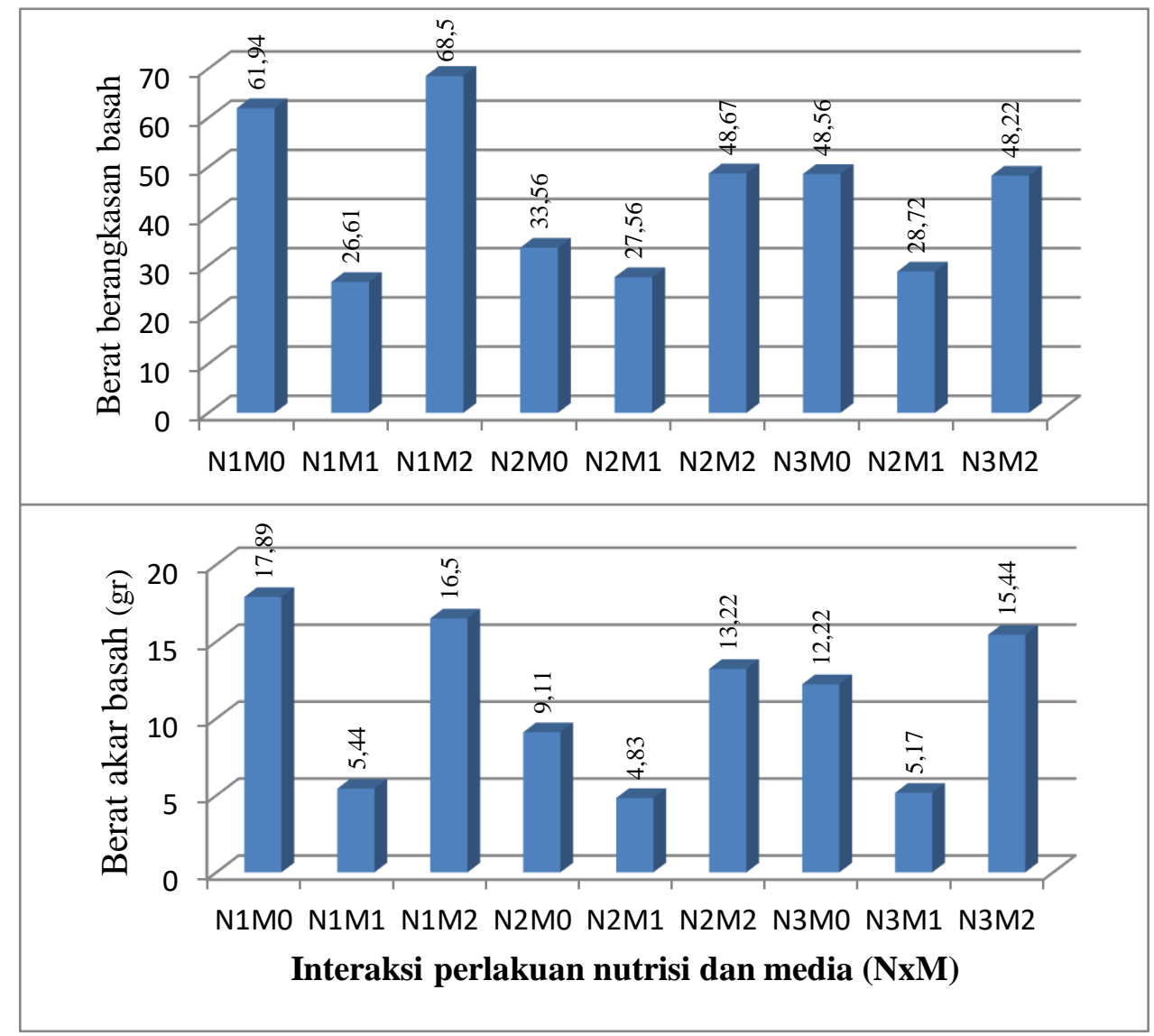

Gambar 6. Pengaruh interaksi perlakan nutrisi dan media (NxM) terhadap berangkasan basah dan berat akar basah

Gambar 6, dapat diketahui berat berangkasan pada N1 M2 menunjukkan hasil yang tertinggi yaitu 68,5 gram, sedangkan nilai terendah pada interaksi N1M1 menunjukkan nilai 26,61 gram. Azis dan Kurnia (2015) mengatakan bahwa penambahan nitrogen yang cukup pada tanaman selada akan mempercepat laju pembelahan sel dan pemanjangan sel, pertumbuhan akar dan daun berlangsung dengan cepat.

Gambar 6, dapat diketahui bahwa berat akar basah pada nutrisi N1M0 menunjukkan hasil yang tertinggi yaitu 17, 89 gram, sedangkan N2M1 menunjukkan hasil yang terendah yaitu 4,83 gram. Akar berfungsi menyerap unsur hara dari dalam larutan dimana semakinpanjang akar maka jumlah rambut akar semakin banyak menyebabkan unsur hara yang terserap akan semakin banyak sehingga kebutuhan akan unsur hara semakin tercukupi (Guritno dan Sitompul, 2006).

\section{KESIMPULAN}

1. Pemberian nutrisi berpengaruh terhadap pertumbuhan tanaman selada pada variabel pengamatan tinggi tanaman, dan lebar daun. Nutrisi AB Mix hanya pada tinggi tanaman 
14 hst, dan NPK mutiara dengan growmore tidak berbeda nyata dengan Urea, TSP, $\mathrm{KCl}$ dan Gandasil D

2. Pengaruh media tanam rockwool berpengaruh terhadap pertumbuhan tanaman selada pada variabel pengamatan jumlah helai daun umur 14 hst, 21 hst, 35 hst, dan 42 hst.

3. Pengaruh interaksi nutrisi dan media,berpengaruh pada variabel pengamatan jumlah helai daun 21 hst, dan panjang daun 21 hst. Variabel pengamatan jumlah helai daun 21 hst pada interaksi N1M0 dan N3M0, variabel pengamatan panjang daun 21 hst pada interaksi N1M0 dan N2M0.

\section{DAFTAR PUSTAKA}

Aisyah, I. 2013. Kajian Penggunaan Macam Air dan Nutrisi pada Hidroponik Sistem DFT (Deep Flow Technique) terhadap Pertumbuhan dan Hasil Baby Kailan (Brassica oleraceae var. alboglabra). Skripsi. Fakultas Pertanian Universitas Sebelas Maret. Surakarta

Azis, A. A., dan N. Kurnia. 2015. Kandungan Amonium dan Nitrat Tanah pada Budidaya Putih dengan Menggunakan Pupuk Urin Manusia. Bionature, 16 (2) : 86 - 90

Fitter A.H. dan Hay, R.K.M. (1991), Fisiologi Lingkungan Tanaman. Universitas Gajah Mada, Yokyakarta

Gardner, P. Franklin, B. R. Pearce, dan R. L. Mitchell. 2007. Fisiologi Tanaman Budidaya. Terjemahan oleh Hermawati, Susilo. Universitas Indonesia. Jakarta

Ginting, C. 2007. Pengendalian Suhu Zona Perakaran pada Pertanaman Selada (Lactuca sativa, L.) Sistem Hidroponik (Disertasi). Universitas Gadjah Mada. Yogyakarta.

Guritno, B. dan Sitompul. 2006. Analisis Pertumbuhan Tanaman. Fakultas Pertanian. Universtas Brawijaya Malang. Malang.

Harjono, I. 2001. Sayur-sayur Daun Primadona. Aneka, Solo. 145 hlm.

Herwibowo, K., Budiana, N. S. 2014. Hidroponik sayuran untuk hobi dan bisnis. Jakarta: Penebar Swadaya.

Irwan, A. W., Wahyudin. A.,dan Farida. 2005. Pengaruh Dosis Kascing Dana Bioaktivator Terhadap Pertumbuhan dan Hasil Tanaman Sawi (Brassicajuncea L.) yang dibudidayakan secara organik. Jurnal Kultivasi.Vol 4 (2). Hal 136-140.

Islami, T., dan W. H. Utomo. 1995. Hubungan Tanah, Air dan Tanaman. IKIP : Semarang Press. $293 \mathrm{hlm}$.

Lingga, P. 2007. Hidroponik Bercocok Tanam Tanpa Tanah. Penebar Swadaya. Jakarta.

Mechram, S. 2006. Aplikasi Teknik Irigasi Tetes dan Komposisi Media Tanam pada Selada (Lactuca sativa). Jurnal Teknologi Pertanian, Vol. 7 (1): 2736.

Mengel, K and Kirkby, E.A. 1978. Principles of Plant Nutrition. International Potash Institute. Bern Switzerland.

Morgan, L. 2005. Powering up the Root System, Growing Edge, Volume 15, Number 4. NewMoon Publishing Cornvallis, Oregon. 
Agritrop, Vol. 18 (1): 38 - 50

Nelson R, 2009, Methode Of Hydroponic Production, Aquaponic Journal Montello, USA.

Pusat Data dan Sistem Informasi Pertanian. 2014. Statistik lahan pertanian tahun 2009 2013. Jakarta: Kementerian Pertanian.

Roidah, I. S. 2014. Pemanfaatan lahan dengan menggunakan sistem hidroponik. Jurnal Universitas Tulungagung Bonorowo 1 (2), 43-50.

Rosliani, R., Sumarni, N. 2005. Budidaya tanaman sayuran dengan sistem hidroponik.: Balai Penelitian Tanaman Sayuran. Bandung

Siswandi dan Sarwono. 2013. Uji Sistem pemberian Nutrisi dan Macam Media terhadap Pertumbuhandan Hasil Selada (Latuca sativa L.) Hidroponik. J. Agronomika. 08 (01) : 144-148.

Sutiyoso, Y. 2013. Meramu Pupuk Hidroponik. Penebar Swadaya. Jakarta. $122 \mathrm{hlm}$

Wijayani, A. dan Didik Indradewa, 2004, Deeteksi Kahat Hara N, P, K, Mg, dan Ca pada Tanaman Bunga Matahari dengan Sistem Hidroponik Dalam: Agrosains - Jurnal Penelitian Agronomi Vol. 6 No. 1:1-4 